Ана Вујовић ${ }^{1}$

Универзитет у Београду

Учитељски факултет
УдК 930.85(=133.1)(100)

$327.39(=133.1)$

811.133.1

DOI 10.18485/zivjez.2016.36.1.1

Прегледни рад

\title{
НАСТАНАК И ЗНАЧЕЊЕ ПОЈМА ФРАНКОФОНИЈЕ
}

У раду најпре дајемо кратак историјат настанка појма франкофоније, потом његове дефиниције односно значења, промене и прилагођавања потребама новог модерног времена и новим животним околностима. У почетку повезане заједничком употребом француског језика у комуницирању, франкофоне земље последњих деценија проширују своје активности на разне области људског деловања. Указујемо пре свега на неопходност да се француски језик данас развија прилагођавајући се језичкој и културној традицији и особеностима бројних франкофоних земаља на пет континената. Представљамо и главне етапе у развоју идеје о франкофонији, као и неке од најважнијих званичних државних и невладиних међународних франкофонских организација.

Кључне речи: франкофонија, француски језик, језички простор, културни простор, политичко-економски простор

Настанак термина франкофонија дугујемо географу Онезиму Реклију (Onésime Reclus), брату познатијег географа Елизеа Реклија (Élisée Reclus). Овај термин употребљен је први пут у делу Француска, Алжир и колоније (France, Algérie et colonies), у којем је аутор позивао на стварање „француске Африке“ уједињене око једног националног језика. Онезим Рекли је и аутор неколико дела о распрострањености француског језика, написаних између 1880. и 1904, дела која су сматрана револуционарним за своје време, јер су за главни критеријум класификовања језика узимала податак у вези са тим који језик

1 ana.vujovic@uf.bg.ac.rs 
становници одређених земаља и крајева користе у свом породичном и друштвеном животу. Како би једном речју означио све крајеве у којима се говори француски, тј. како би означио језичко и културно јединство које чине Француска и њене колоније, створио је термин франкофонија (francophonie). Дефинисао је и многе елементе садржаја овог појма које ми и данас прихватамо: предложио је да се разликују људи који су франкофони по рођењу од оних који га редовно користе, али којима то није матерњи језик; указао је и на то да универзалност која се обично повезује са појмом франкофоније није последица демографских разлога, односно великог броја говорника, већ чињенице да је француски језик у широкој међународној употреби; подвлачио је повезаност језика са културом и чињеницу да је француски језик био прихватан и као средство ширења слободарских и хуманистичких идеја Револуције. Као и многи његови савременици у Француској, веровао је да та земља има значајну цивилизаторску улогу у многим неразвијеним деловима света, те да је језик можда и најважнији инструмент у вршењу те мисије.

Иако овај термин раније није коришћен, основа онога што ће он означавати настала је још у 16. веку, са почецима стварања француског колонијалног царства, премда данашњи појам франкофоније има шире значење, а пре свега означава једну на сасвим другачијим основама утемељену групу међусобно повезаних држава. Њихова повезаност почела је од заједничке употребе француског језика, да би се временом ширила и на друге области људског деловања и довела до стварања добро устројене међународне организације која окупља многе земље око истих вредности.

У првој половини 20. века не употребљава се појам франкофонија (francophonie), већ у речницима постоји само придев

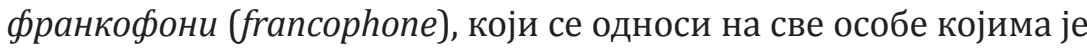
француски матерњи језик. У то време постоји појам francité, који означава све што је у вези са француским језиком, културом и духом. Појам франкофоније поново постаје актуелан тек 1962. када га је употребио сенегалски писац и државник Леополд Седар Сенгор (Léopold Sédar Senghor) у сада већ чувеном новем- 
барском броју часописа Esprit, броју који се сматра првим манифестом франкофоније. Појам доживљава вртоглав успон, о њему пишу и подржавају га бројни угледни политичари и ерудите, као што су: принц Сиханук из Камбоџе (Norodom Sihanouk), председници Туниса, Либана и Нигерије Бургиба (Habib Bourguiba), Елу (Charles Hélou) и Диори (Hamani Diori). Шездесетих година 20. века, у време када су бројне француске колоније, ратом или мирним путем, стекле политичку, али не и економску независност, постало је јасно да им је неопходна нека врста повезивања, како са Француском, тако и међусобно. Имајући у виду да се Француска чувала било каквих активности које би могле бити схваћене као одраз неоколонијализма, промоцију франкофоније започели су страни државници и интелектуалци, често управо они који су народе својих земаља предводили у борби за независност, али којима је био очигледан културни престиж Француске и неоспорна потреба блиске повезаности са њом. Стога се поменути политичари и државници сматрају очевима, односно родоначелницима франкофоније, који су одиграли кључну улогу у стварању организованих институција франкофоније. Путовали су по бројним афричким, арапским и азијским земљама и радили на ширењу идеје о потреби и предностима постојања једне овакве организације. (Бле 2010: 34-36) Међународна организација франкофоније замишљена је и основана као нека врста идеала о уједињењу народа који користе француски језик, а то хумано и људско лице франкофоније привукло је тада, а привлачи и данас, бројне познате и угледне личности из света интелектуалаца, писаца, филозофа, професора хуманистичких дисциплина, што потврђује и чињеница да су међу њеним родоначелницима били и један реномирани песник (Сенгор) и један пасионирани списатељ и професор књижевности (Сиханук); касније се придружују и многи писци, међу којима су Еме Сезер (Aimé Césaire) са Антила, Жан Амруш (Jean Amrouche) из северне Африке, Шарл-Фердинан Рамиз (Charles-Ferdinand Ramuz) из Швајцарске, Гастон Мирон (Gaston Miron) из Квебека или Шарл де Костер (Charles De Coster) из Белгије.

По многима, Међународна организација франкофоније је, од свих удружења која су настала на темељима заједничког 
Ана Вујовић

језика (као што су Комонвелт, Лига арапских држава, Организација иберо-америчких земаља итд.) најхетерогенија, са највећом разноврсношћу сасвим различитих култура, традиција, политичких режима, економских система, религија и локалних језика. Франкофонија уједињује најбогатије и најсиромашније, најразвијеније и најнеразвијеније земље света; чине је невероватни контрасти, што је по мишљењу једних предност, а по мишљењу других слабост и препрека за озбиљнију сарадњу. Франкофонија се управо и дичи тиме да је организација која највише ради на очувању разноврсних вредности, култура, идентитета, погледа на свет и на њиховом мирном истовременом постојању. Насупрот растућој опасности од униформног света којим доминира само један језик и једна култура, Франкофонија све снажније инсистира на разноликости, што условљава и доношење неких значајних међународних докумената (попут Опште декларације Унеска о културној разноликости /Déclaration universelle de l’Unesco sur la diversité culturelle/ из 2001. или Конвенције о заштити и промовисању разноликости културних израза /Convention sur la protection et la promotion de la diversité des expressions culturelles/ из 2005).

У називима првих удружења и организација није било појма франкофонија или франкофони, али се они јављају у речницима већ седамдесетих година 20. века, да би касније постали општеприхваћени. Да бисмо боље разумели ове појмове, потребно је дати њихово ближе одређење и указати на разлике које постоје међу одређеним терминима. Именица франкофонија и придев франкофони/франкофонски користе се од 1980. често као синоними, али се заправо односе на три појма:

$\checkmark$ франкофонија (са малим почетним словом ф) означава све народе или групе говорника који делимично или у потпуности користе француски језик у свакодневном животу и комуникацији; осим овог, лингвистичког и географског одређења, реч има и духовни и институционални смисао (припадност истој духовној заједници солидарности, равноправности и сарадње);

$\checkmark$ Франкофонија (са великим почетним словом Ф) означава Међународну организацију франкофоније, МОФ (Organisation internationale de la francophonie, OIF) - скуп зе- 
маља, влада или званичних институција које користе француски језик у пословању и размени; то је добро устројена и структурисана међународна организација, која је представљена у Уједињеним нацијама, при Европској унији и у бројним другим међународним организацијама;

$\checkmark$ франкофонски простор не представља само географску или језичку, већ и културну, политичку и економску одредницу; он окупља све оне који осећају или исказују извесну припадност француском језику или франкофоним културама, односно деле неке заједничке вредности, преносе их и размењују управо захваљујући француском језику. Може се одредити као тројаки простор:

- Географски и лингвистички простор сасвим је очигледан - окупља 80 земаља са пет континената, а њима је заједничка искључива или делимична употреба француског језика у различитим аспектима живота и рада.

- Културни простор повезује културне активности народа са ових пет континената. Све велике културе (па и оне античке, грчка и римска) биле су мешавина различитих утицаја и вредности, и управо то је чинило њихову снагу и лепоту. Медији и модерни начини комуникације данас ову повезаност чине још лакшом, бржом и очигледнијом, а извесно је да ће у будућности то бити још и израженије.

- Политичко-економски франкофони простор све се више развија и постаје најважнији, јер нуди могућност развоја неразвијенима. Постоје огромне разлике у нивоу развијености и висини бруто националног прихода: према подацима са краја 20. века, само четири земље (Француска, Канада, Швајцарска и Белгија) остваривале су 90\% прихода у франкофоном економском простору, док су све остале земље (којих је тада било око 40 ) остваривале око 10\% укупног прихода (Тети 1997: 96). Данас ова организација обухвата 54 земље пуноправне чланице, 23 земље посматрача (међу којима је и Србија) и 3 земље са статусом придруженог члана. ${ }^{2}$

2 http://www.francophonie.org/-80-Etats-et-gouvernements-.html 
У политичком смислу, међу франкофоним земљама има и великих и малих (и по површини и по броју становника), оних са дугом дипломатском традицијом и оних недавно насталих, континенталних и острвских, из разних климатских појасева и са најразноврснијим културним традицијама, мање или више повезаних унутар разних међународних организација, са различитим државним уређењем, идеолошком и верском припадношћу. Разликују се и облици сарадње који државама одговарају, па тако две државе које су највећи финансијери ове организације, Француска и Канада, немају исте ставове по питању сарадње: док Француска више воли билатералне облике сарадње, јер сматра да тако задржава свој утицај (мада не одбацује ни мултилатералне), Канада види прилику за контакте са свим регионима и тежи мултилатералној сарадњи.

Франкофоне земље су све оне земље у којима је француски језик присутан као:

- матерњи језик (Француска, Белгија, Швајцарска, Луксембург, Монако, Квебек);

- званични језик (на пример, Сенегал, Нова Каледонија, Гвајана итд.);

- језик школовања и свакодневног комуницирања (на пример, Мали, Мадагаскар, Обала Слоноваче итд.);

- привилегован страни језик (као у Мароку или Тунису, на пример).

Некада се сматрало да се појам франкофоније односи на франкофоне земље изван Француске, па је свет франкофоније и представљан као низ концентричних кругова у чијем центру се налазила Француска. Први круг око ње чиниле су земље и регије у којима је француски био матерњи језик (Белгија, Швајцарска, Луксембург, Монако, Долина Аосте, Квебек). Потом је следио круг са земљама у којима је француски био национални или званични језик (Мартиник, Гвајана, Доминикана, Реунион, Хаити, Гваделуп, Сен Луси), па круг са онима у којима је француски језик комуникације и културе (Тунис, Мароко, Алжир, Либан, Мадагаскар, земље црне Африке, Румунија, Бугарска итд.). 
Овакав начин приказивања могао је изгледати тачно све док се сматрало да је Француска центар франкофоног света, али од 1990. (када Француска исказује жељу да се јасније дистанцира од своје колонијалне прошлости) преовлађује став да је Француска само једна од франкофоних земаља, тако да је ову кружну представу франкофоније заменила нешто разућенија и модернија, у којој, због све већег међусобног утицаја култура, франкофонија има више центара: западна Европа, централна и источна Европа, Азија, Блиски исток, Магреб, Африка, Индијски океан, Пацифик, Кариби, Северна Америка. Овакав начин приказивања сведочи и о свести да се, и поред несумњивих разлика у степену економске развијености међу франкофоним земљама (што утиче и на степен финансијске помоћи које одређене земље дају или примају у оквиру Међународне организације франкофоније), међу њима не сме и не може успостављати било каква врста хијерархије нити да било коју земљу треба сматрати оном која одлучује о активностима организације (Вујовић 2014: 47).

Времена и околности се мењају, као и потребе корисника, па им се језик (као средство-алат за комуникацију) мора прилагођавати ако жели да опстане, а посебно ако жели да се развија и да повећава број говорника. Уколико француски језик жели да буде присутан у афричким земљама, на пример (а управо говорници француског језика са овог континента највише доприносе порасту броја франкофоних особа у свету), те да се на њему и говори и пише, и то не само у уским круговима интелектуалаца, често образованих у Француској, онда он мора да постане афрички језик, односно да га прихвате и њиме се, на задовољавајућем нивоу и у свим доменима свакодневног живота, служе сви становници у афричким франкофоним земљама, а не само интелектуална елита.

Варијетети француског језика веома су бројни, посебно је то видљиво у области лексике, па је 1997. објављен и први Општи франкофони речник (Dictionnaire universel francophone), са преко 116.000 дефиниција, 13.000 одредница у вези са властитим именима и кратким граматичким додатком. Француски 
језик је постао заједничко добро франкофоног света које служи преношењу различитих култура, те мора у себе да прихвата речи повезане са свакодневним животом, географијом, традицијама и друштвеном организацијом бројних франкофоних народа. Овакви облици регионалних особености и народног стваралаштва нису нешто што ће га покварити и осиромашити, сматрају неки стручњаци (попут Шарла Балија, Жила Марузоа или Андреа Мартинеа /Charles Bally, Jules Marouzeau, André Martinet/), већ би пре то могли да учине језички пуританци и снобови, који желе да га затворе, изолују и стерилишу (Тети 1997: 58).

\section{Главне етапе у развоју идеје о франкофонији}

Ако се жели издвојити неколико основних фаза у развоју идеје франкофоније, мислимо да би следећа подела била најпрегледнија:

1. Од настанка појма осамдесетих година 19. века, преко настанка разних професионалних франкофонских удружења до шездесетих година 20. века: француски језик је био тај који је окупљао људе из разних крајева света које су повезивале сличне професионалне активности и идејне вредности.

2. Од почетка седамдесетих, до средине осамдесетих година 20. века, све се више и организованије ангажују државе и владе бројних земаља на пет континената, са жељом да развијају разне облике сарадње.

3. Од 1986. године почиње се са одржавањем састанака шефова држава и влада земаља Франкофоније, и то читавој организацији даје нову политичку димензију. Настају и неки оператери Франкофоније (Универзитетска агенција франкофоније, франкофони телевизијски канал ТВ5 Монд, Универзитет Сенгор у Александрији и Међународно удружење франкофоних градоначелника), покрећу се Игре Франкофоније, а организација се све озбиљније бави важним социолошким и правним питањима (попут положаја жена, бриге о деци, образовања итд.). 
4. Крајем деведесетих година мења се управљање Међународном организацијом франкофоније, на чије чело долази генерални секретар, чија ће задужења и овлашћења постати значајнија и свеобухватнија. Појачава се економска и политичка сарадња и солидарност међу државама, ради на професионалном усавршавању стручњака из неразвијених земаља, установљавају се награде за доприносе у разним областима.

5. Од почетка овога века, администрација Међународне организације франкофоније све је разуђенија, надлежности су јасније раздељене, а све се више инсистира на језичкој и културној разноликости као основном предуслову слободног и праведног живота у модерном друштву. ${ }^{3}$

\section{Неке од најважнијих званичних државних и невладиних међународних франкофонских организација}

Прве франкофонске организације (настале у Француској или у Канади и Белгији, али подстакнуте идејама из Француске) биле су невладине, а њихов циљ био је унапређење наставе и употребе француског језика, валоризовање француске културе независно од успона и падова у француској политици, успостављање веза које би допринеле ширењу француског утицаја.

Најстарија и можда најпознатија франкофонска невладина организација јесте Француска алијанса (Alliance française), основана 1883. у Паризу. Међу њеним члановима има славних имена из разних домена интелектуалних делатности, као што су научник и лекар Луј Пастер (Louis Pasteur), људи од пера Иполит Тен (Hippolyte Taine) и Ернест Ренан (Ernest Renan), дипломата Фердинан де Лесепс (Феrdinand de Lesseps) /заслужан за просецање Суецког канала/, бројни црквени великодостојници Католичке цркве и Јеврејске верске заједнице, као и многи

3 о неким од најважнијих датума у вези са Франкофонијом видети на: http://www.francophonie.org/spip.php?page=page_frise_chronologique 
други. До краја 19. века широм света је било отворено 250 школа за учење француског језика, а почетком 21. века има 420.000 ученика у преко 1000 огранака у 136 земаља, на пет континената. Једна од њених основних идеја била је одувек да не буде строго централизовано организована, већ да свака земља има заправо свој национални центар којим управља према локалним законима, а који само носи име Француска алијанса. Осим самог учења језика, активности су многобројне и врло амбициозне: конференције, изложбе, представе, предавања итд. Интересовање је све јаче у последњих десетак година, па се, посебно у Кини и Русији, отварају нова представништва Алијансе или локална удружења која са Алијансом блиско сарађују.

Двадесетак година после Француске алијансе основана је у Паризу, 1902. године, Световна мисија (Mission laïque), која доследно спроводи идеју о раздвојености цркве и државе, односно њеног образовног система. За разлику од Алијансе, која се бави наставом француског језика, Световна мисија и данас организује целокупан образовни циклус, отварајући школе, гимназије и институте (прва неконфесионална школа отворена је у Солуну 1906). ${ }^{5}$ Њени образовни приоритети односе се на јачање знања језика и добијање одговарајућих сертификата, затим, на отварање ка локалној култури и на образовање деце као будућих грађана са израженом еколошком свешћу.

Борбу за очување француског језика становници Квебека (окружени већински англофоним становницима протестантске вероисповести) доживљавали су и као борбу за очување националног идентитета и верске слободе, односно припадности католичкој цркви. Почетком 20. века створено је Друштво за француски говор (Société du parler français), милитантна лингвистичка организација која ће прерасти у удружење Говоримо боље (Parlons mieux), које је истраживало особености француског језика у Канади и редовно објављивало свој билтен. У периоду између два светска рата основан је Стални коми-

4 Детаљније на: http://www.alliancefrorg.

5 О циљевима, активностима, мрежи, начину приступања овој мисији и њеним издањима видети на: http://www.mlfmonde.org/. 
тет за опстанак француског (Comité permanent de la survivance française), а затим, 1952. године, и Савет за француски живот у Америци (Conseil de la vie française en Amérique).

И у Белгији се мислило на развој француског језика и судбину франкофоног света, иако су у тој земљи франкофони Валонци били бројнији, а ни Фламанци тада нису одбијали да говоре француски језик. Од почетка 20. века, оснивани су: Удружење белгијских писаца на француском језику (Association des écrivains belges de langue française), Краљевско удружење валонских писаца (Association royale des écrivains wallons), Краљевска академија за француски језик и књижевност у Белгији (Académie royale de langue et de littérature françaises de Belgique).

У време Другог светског рата, док је привремена француска влада, са Де Голом на челу, боравила изван Француске, а издавачка делатност у земљи била сведена на минимум, Канада и Антили су осетили да је пред њима нова велика мисија: очување француског језика и враћање његовог угледа. Овим напорима се после рата придружују и друге франкофоне земље које планирају окупљање земаља из различитих делова света, али око француског језика као заједничког, као и стварање нових међународних удружења. Под руководством Ренеа Касена (René Cassin), састављача Декларације Уједињених нација о правима човека 1948. и добитника Нобелове награде за мир, године 1964. основан је Међународни институт за француско и остала на њему заснована права (Institut international de droit d'expression et d'inspiration françaises, IDEF), који је окупљао правнике и све заинтересоване за право у земљама које користе француски језик или су под утицајем француске правне традиције. На иницијативу политичара, нарочито афричких, у Луксембургу се 1967. ствара Међународно удружење франкофоних парламентараца (Association internationale des parlementaires de langue française, AIPLF). Велики број различитих невладиних франкофонских организација, јавних и приватних, осниван је изван саме Француске, а њихове чланове углавном је повезивала иста професионална усмереност 
(удружења франкофоних писаца, економиста, социолога, зубара, агронома, спортских лекара итд.). Њихове координиране активности на очувању, промоцији и осавремењивању француског језика годинама су утицале на јачање франкофонске свести и у великој мери отвориле пут за стварање званичних државних франкофонских институција.

Међународна федерација професора француског језика (Fédération internationale des professeurs de français, FIPF) има статус међународне невладине организације, настала је 1969, а обухвата 186 националних удружења у 140 земаља. Од 2000. године Федерација је задужена и за издавање часописа Француски у свету (Le Français dans le monde). Настала из страха од слабљења позиције француског језика у међународној комуникацији, ова федерација организује научне скупове и семинаре на свих пет континената, игра значајну улогу у дифузији књижевности франкофоних земаља и у упознавању њихових култура. Рад се одвија у оквиру регионалних комисија којих има осам (Комисија за француски као матерњи језик, затим, комисије за Африку и Индијски океан, за Северну Америку, за Азију и Пацифик, за централну и источну Европу, за западну Европу, за арапски свет, за Латинску Америку и Карибе). Циљ Федерације је да унапреди наставу француског језика у читавом свету, да прошири дијалог и размене искустава међу професорима француског језика, подржи и унапреди израду педагошких материјала, удружи снаге свих који се залажу за развијање комуникације на француском и допринесе да француски језик остане важна компонента у развоју вишејезичности и дијалога међу културама (Вујовић 2011: 298-299).

Током година стварана су и разне стручна удружења, попут: Међународног франкофонског удружења директора школских установа (Association francophone internationale des directeurs d'établissements scolaires, AFIDES) или Франкофонског комитета синдиката образовања и стручног оспособљавања (Comité syndical francophone de l'éducation et de la formation, CSFEF), чија су седишта у Монтреалу. Године 1981. основано је Национално удружење наставника француског као 
страног језика (Association nationale des enseignants de français langue étrangère, ANEFLE), a 1985. Удружење за методику француског као страног језика (Association de didactique du français langue étrangère, ASDIFLE).

Агенција за француско образовање у иностранству (Agence pour l'enseignement français à l'étranger, AEFE) окупља француске образовне институције (основне школе, колеже и гимназије) које функционишу изван Француске, али по француским наставним програмима. Школске године 2005/06. било је 429 таквих школа у 128 земаља света, међу којима је и Србија (Пуасоније 2006: 34-35), а читавом овом мрежом школа руководи Министарство иностраних послова.

Француска у свету има и преко 430 културних центара и института у 150 земаља, а у њима француски језик учи 600.000 људи. Добро опремљене медијатеке и информациони центри извор су занимљивог и разноврсног материјала о савременој француској култури, стручњаци из разних области и потенцијални студенти на франкофоним универзитетима ту могу добити потребна обавештења и подршку. Ове институције особито су значајне за стратегије јачања вишејезичности и промовисања француског језика у разним регионима света.

Високи Савет Франкофоније (Haut Conseil de la Francophonie), створен је у марту 1984. у Француској, на иницијативу тадашњег француског председника Франсоа Митерана (François Mitterrand). Састављен од угледних француских личности, имао је за задатак да саветује француског председника и да предлаже активности у вези са франкофонијом. Сваке друге године објављује Стање франкофоније у свету (État de la francophonie dans le monde), као и друге тематске публикације. Настао је преузимајући области деловања Високог комитета за француски језик (Haut Comité de la langue française), који је основао председник Жорж Помпиду (Georges Pompidou), а функционисао је од 1966. до 1984. године. Променио је донекле начин рада 2004, јер се усмерио на мултилатералну сарадњу (праћење лингвистичких промена у државама и међународним организацијама, праћење и анализу стања у 
франкофонији, предлагање начина за побољшање положаја француског језика и за бољу политичку активност франкофоније). Назив под којим га јавност познаје остао је исти, иако је званични промењен у Консултативни савет франкофоније (Conseil consultatif de la francophonie).

Сажет хронолошки преглед настајања само неких, по нашем мишљењу, важних догађаја и манифестација у франкофоном свету, показује колико су такви догађаји, који су се испрва збивали у размацима од неколико, па чак и више од десет година, све учесталији, тако да у последње две деценије нема године без значајних и бројних дешавања, што само говори о интензивирању рада на повезивању франкофоних земаља. Занимљиво је, такође, уочити и у којим се областима најпре успоставља сарадња и како се активности временом обогаћују и мењају. Наравно, ово није преглед свих њих, већ репрезентативни приказ њихове разноврсности, са указивањем на почетке одређених активности и на настајање неких франкофонских организација.

- 1926. Удружење писаца на француском језику;

- 1950. Међународна унија новинара и штампе на француском језику (данас Унија франкофонске штампе);

- 1960. Конференција министара просвете франкофоних земаља (Confémen);

- 1961. Удружење универзитета који делимично или у потпуности користе француски језик (данас Универзитетска агенција франкофоније); Међународни институт за француско и остала на њему заснована права;

- 1967. Међународно удружење франкофоних парламентараца (данас Парламентарна скупштина франкофоније);

- 1969. Конференција министара за омладину и спорт франкофоних земаља (Conféjes); Међународна федерација професора француског језика;

- 1970. - 20. марта потписан је уговор о стварању Агенције за културну и техничку сарадњу (данас Међународна организација франкофоније); Међународна унија франкофонске штампе (Зато је 20. март и проглашен Међународним даном франкофоније); 
- 1974. Обележавање прославе франкофоније Међународним фестивалом франкофоне омладине Superfrancofête у Квебеку;

- 1978. Међународни савет за радио и телевизију на француском језику; Агенција за културну и техничку сарадњу постаје посматрач у Уједињеним нацијама;

- 1984. Франкофонски телевизијски канал ТВ5;

- 1986. Први састанак шефова држава и влада франкофоних земаља у Версају (овакви састанци на врху и даље се одржавају сваке друге године у некој другој франкофоној држави);

- 1986. први Центар за читање и културну анимацију;

- 1988. Институт Франкофоније за енергију и животну средину; Франкофонски фонд за аудио-визуелно стваралаштво неразвијених земаља Југа;

- 1989. прве Игре Франкофоније; Универзитет Сенгор у Александрији;

- 1995. Међународно удружење франкофоних градоначелника постаје оператер Међународне организације франкофоније; одлука о установљењу звања сталног Генералног секретара Франкофоније;

- 1997. Повеља о Франкофонији је усвојена и установљено је место Генералног секретара Франкофоније;

- 1998. Бутрос Бутрос-Гали, некадашњи генерални секретар Организације уједињених нација, изабран је за генералног секретара Франкофоније; стварање Института за нове информационе технологије и образовање (данас Франкофонски информатички институт); стварање Фонда за помоћ франкофонској штампи у неразвијеним земљама Југа;

- 2000. Међународни симпозијум о демократији, правима и слободама (Бамако, Мали) на којем је усвојена значајна Декларација из Бамака; Конференција жена Франкофоније;

- 2001. Награда пет континената за роман на француском језику; Министарска конференција о култури; лабораторије за обуку у области нових технологија /LabTIC/; Франкофонска мрежа дигиталних националних библиотека

- 2002. план активности у вези са положајем француског језика у оквиру Европске уније; 
- 2004. први стратешки десетогодишњи план Франкофоније, који дефинише њене четири велике мисије: промовисати француски језик и језичку и културну разноликост; промовисати мир, демократију и људска права; подржати образовање, високо образовање и истраживачки рад; развијати солидарност и сарадњу за одрживи развој;

- 2005. Међународна организација франкофоније добија то име (пошто је најпре била Агенција за културну и техничку сарадњу, па Међувладина агенција франкофоније); програм за јачање положаја француског језика у афричким организацијама;

- 2006. фестивал Франкофонија у Француској;

- 2009. прва Кућа знања Франкофоније отворена у Вијетнаму;

- 2010. обележавање 40 година постојања Међународне организације франкофоније;

- 2012. све већа пажња посвећује се: заштити животне средине, економској кризи, питањима везаним за информатичко друштво, развој дигиталних ресурса и њихову примену у образовању (Вујовић 2014: 116-119).

\section{Уместо закључка}

Желели смо да укажемо на дуготрајност, важност и озбиљност разноврсних активности унутар франкофоног света и посебно Међународне организације франкофоније. Не треба заборавити ни чињеницу да у многим крајевима расте број оних који уче француски језик (највише у Африци и на Средњем истоку, потом у Кини и Индији, у Канади и Латинској Америци), што значи да расту и могућности да се са бројним стручњацима из различитих земаља сарађује и комуницира на француском језику. У исто време код нас опада број оних који у оквиру образовног система уче француски језик, све је мање младих научних истраживача и универзитетских сарадника и наставника који се служе француским језиком, што за собом повлачи и све слабије коришћење научне и стручне литерату- 
ре на француском језику, што опет за последицу има све мањи број студената који се одлучују да уче овај језик, и тако се затвара зачарани круг из којег је врло тешко изаћи. На жалост, наши студенти и млади научници не искористе све стипендије које им влада Француске нуди сваке године, у највећој мери управо због недовољног владања француским језиком.

И поред свих наведених чињеница, код нас као да постоји сумња у важност франкофоније. Можда то и није сумња, јер сумња ипак претпоставља бар неки ниво знања и информисаности о нечему; пре је реч о незнању, незаинтересованости, одсуству размишљања о будућности и о развоју, непостојању озбиљне језичке политике на нивоу државе. Политика и економија не би смеле да искључују културу, али се чини да они који највише и размишљају о повезаности економије и културе ту везу сагледавају искључиво кроз могућност да оно што се ствара у култури донесе и што већу зараду. Нека питања остају без одговора: зашто се о франкофоном покрету и организацији тако мало зна код нас, зашто се о њима говори углавном само током месеца марта (који је Месец франкофоније), зашто практично нема истраживања на тему франкофоније (осим када је реч о књижевностима неких франкофоних земаља)? Зашто је присуство француског језика и културе у нашој средини све слабије, а учење овог важног и великог светског језика постаје све више скрајнуто у односу на неке друге језике?

\section{ЛИТЕРАТУРА}

Бле 2010: Bleys, О. (2010). Voyage en Francophonie. Paris: Éditions Autrement.

Вујовић 2011: Вујовић, А. (2011). Српско-француска сусретања. Београд: Учитељски факултет.

Вујовић 2014: Вујовић, А. (2014). Франкофонија у свету и код нас. Београд: Учитељски факултет.

Пуасоније 2006: Poissonnier, A. et Sournia, G. (2006). Atlas mondial de la francophonie - Du culturel au politique. Éditions Autrement, Coll. Atlas/Monde. 
Тети 1997: Tétu, M. (1997). Qu'est-ce que la francophonie ? Paris: Hachette-Edicef.

http://apfs.edu.rs/

http://fipf.org

http://www.alliancefr.org

http://www.francophonie.org/-80-Etats-et-gouvernements-.html

http://www.francophonie.org/spip.php?page=page_frise_chronologique http://www.mlfmonde.org/

\section{Ana Vujović}

\section{LA CRÉATION ET LE SENS DE LA NOTION DE FRANCOPHONIE}

\section{Résumé}

La notion de francophonie date de l'année 1880 comme trouvaille terminologique du géographe Onésime Reclus. Au sens général, la francophonie est l'ensemble des pays francophones, ceux où l'on parle français. Toutefois, le mot revêt aussi un autre sens - celui de rassemblement des pays adhérents à l'Organisation internationale de la francophonie (OIF), en qualité de membres ou d'observateurs. Nous traitons les définitions de la notion de francophonie, et présentons l'histoire de la francophonie, ainsi que certaines organisations gouvernementales et non-gouvernementales francophones et leurs activités. De toutes les alliances à base linguistique formées dans le monde, la Francophonie est peut-être la plus hétérogène, avec une énorme variété de cultures, de traditions, de régimes politiques, de systèmes économiques, de religions et de langues. Pour certains, cette manque de cohésion est une vulnérabilité, et pour d'autres l'atout premier et la force de la Francophonie qui garantit seule la pluralité des identités, des valeurs, des points de vue et leur coexistence pacifique au sein de la communauté. Dans un monde de plus en plus dominé par une seule langue et une seule culture, la Francophonie ne cesse d'affirmer sa foi dans la diversité et dans la préservation des patrimoines. Nous croyons profondément que la langue et la culture française, ainsi que les cultures francophones, avec toute leur richesse et diversité des sons et des couleurs, méritent d'être plus présentes dans la vie et l'esprit du monde 
contemporain, et surtout dans notre pays (vu l'histoire remarquable des relations franco-serbes).

Mots-clés: francophonie, langue française, espace linguistique, espace culturel, espace politique et économique

Примљено 3. септембра 2016. године Прихваћено за објављивање 15. новембра 2016. године 